A N N A L E S

UNIVERSITATIS MARIAE CURIE-SKŁODOWSKA

LUBLIN - POLONIA

VOL. LXVI, 1

SECTIO G

2019

Uniwersytet Jagielloński w Krakowie

MICHAŁ JASKÓLSKI

michal.jaskolski@uj.edu.pl

\title{
Upodobania i pasje hofrata Kazimierza Chłędowskiego
}

Hofrat Kazimierz Chłędowski’s Interests and Avocations

Przez 30 lat od śmierci musiały spoczywać w pudle w Bibliotece Jagiellońskiej, zgodnie z życzeniem autora, pamiętniki i dokumenty Kazimierza Chłędowskiego, zanim można było je przejrzeć i opublikować. Stało się to niemal natychmiast, choć w czasach niezbyt sprzyjających dla tego typu publikacji. Jest to niepodważalną zasługą Antoniego Knota, który już w 1951 r. przygotował, opatrzył wnikliwym wstępem i przypisami pierwsze ich wydanie, a następnie drugie (uzupełnione), które ukazało się w 1957 r. Wywołały one pomimo owych 30 lat liczne komentarze prasowe o różnej tonacji. Pisali wówczas m.in. Stefan Kisielewski, Julian Tuwim, Aleksander Bocheński, z Londynu zaś Stanisław Cat-Mackiewicz, a z Wiednia Otto Forst de Battaglia. Można rzec śmiało, że ich sukces był miarą tak popularności, jak i w jakiejś mierze skandalu. Dla historyków różnych specjalizacji stały się owe Pamiętniki jednym z najcenniejszych źródeł wiedzy o czasach kształtowania się i rozwoju autonomii galicyjskiej, jak również funkcjonowania i praktyki służby publicznej w monarchii austro-węgierskiej. Jest to zaledwie jedna $\mathrm{z}$ warstw tego dzieła. Do innych należą jeszcze charakterystyki wielu czołowych polityków tego okresu, ze szczególnym uwzględnieniem prominentnych przedstawicieli Koła Polskiego oraz środowiska arystokracji i szlachty galicyjskiej, tudzież biurokracji kraju koronnego, gdzie nie brak anegdot i plotek dodających swoistego kolorytu. Istnieje ponadto warstwa: jego prywatności; ludzi, z którymi wiódł życie przyjacielskie i towarzyskie; jego rozterek i dość licznych romansów, gdy owdowiał; tytułowych upodobań dla historii kultury i sztuki, które tak naprawdę stały się głównym tematem jego późniejszej (już publikowanej) twórczości.

Przedmiotem tego eseju nie jest jednak ani próba przedstawienia dokładnego życiorysu Chłędowskiego, ani pełnej bibliografii obfitej twórczości dzienni- 
karsko-literacko-historycznej, której zresztą jak dotąd nie ma, ani wreszcie chęć analizowania ewolucji, jaką przeszedł od pionierów pozytywizmu galicyjskiego, poprzez biurokratycznego konserwatystę, do nader kompetentnego może i amatora, lecz zarazem wytrawnego znawcy historii sztuki i kultury w jej szerokim wymiarze. Sam mógł się uważać za konserwatystę, lecz pozostał wolnomyślicielem, zdecydowanym antyklerykałem i poniekąd sybarytą, będąc jednocześnie wrogiem romantyzmu i wszelkiej irredenty. Znał osobiście wszystkich autorów Teki Stańczyka, lecz środowisko krakowskie (może poza Stanisławem Koźmianem i dziełami Juliana Klaczki) pozostawało mu obce, podobnie jak krytyczny stosunek do twórczości Jana Matejki. Z racji zatrudnienia bliższe mu było środowisko Lwowa, choć nie na tyle, by nie dostrzegał miałkości, niekompetencji i partykularyzmu w działaniu administracji oraz faktycznego zacofania gospodarczego Galicji. Każdy etap jego życia pozostawił jednak ślad w jego światopoglądzie, a także w twórczości literackiej. Dlatego Chłędowski nader wnikliwie i chyba trafnie przedstawił np. zasługi Agenora hr. Gołuchowskiego st. jako promotora repolonizacji niemal wszystkich dziedzin życia Galicji, rolę Juliana Dunajewskiego jako ministra finansów w gabinecie Eduarda Taaffego czy kulisy obalenia rządu premiera Kazimierza Badeniego, a jednocześnie ze smakiem i wyczuciem opisał wystawy dzieł sztuki w Wiedniu, Monachium czy Paryżu, dostrzegając talent Józefa Mehoffera czy Olgi Boznańskiej. Poza tym podziwiał zasługi naukowe i muzealnicze Karola hr. Lanckorońskiego i nie bez złośliwości dostrzegał ignorancję w zakresie „kolekcjonerstwa” Leona hr. Pinińskiego, którego darzył pewną sympatią i z którym nie mógł konkurować z racji majątku, pozycji politycznej tudzież kariery uniwersyteckiej. Opisał Wojciecha hr. Dzieduszyckiego, którego zdecydowanie nie lubił, a także zupełny brak gustu w wystroju gabinetu ówczesnego jeszcze biskupa Jana Puzyny. Z niesmakiem wspominał nudę i rutynę pracy biurowej, ale opisał też ciepłe i przyjacielskie stosunki z Heleną Modrzejewską czy Henrykiem Sienkiewiczem, choć i tu nie brak zabawnych anegdot. Poza tym plotkował ironicznie o dworsko-arystokratycznych skandalach i nieco naiwnie żywił cześć dla Cesarza oraz wyrażał wiarę w jego szczególną łaskawość dla Polaków jako wyróżnianą przezeń nację. Z tej racji Pamiętniki są kluczem do wielu ocen, sądów, a wreszcie doboru postaci, np. w pracach Rzym. Ludzie Odrodzenia, Rzym. Ludzie Baroku czy Dwór w Ferrarze, nie wspominając o pozostałych równie monumentalnych dziełach.

Rodzi się więc naturalnie pytanie, kim był Chłędowski i jakie warunki ukształtowały jego złożoną osobowość. Ograniczę się tu jedynie do kilku uwag, zawartych zresztą w jego wspomnieniach i biogramach, tym bardziej że w dobie internetu dotarcie do nich nie nastręcza większych trudności. Chłędowski, urodzony w Lubatówce (powiat krośnieński) 23 listopada 1843 r., został zawodowym biurokratą niejako z przymusu, a nie z dobrowolnego wyboru. Sprawa wydaje się dość oczywista i jest typowa dla ówczesnej Galicji. Rodzinny majątek Wietrzno 
był zbyt skromny, by dać względnie dobre utrzymanie całej rodzinie, stąd ojciec autora - jak mawiało się wówczas - „chadzał dzierżawami” i administracjami cudzych majątków. Mamy tu do czynienia z dość klasyczną sytuacją postępującej deklasacji sfery drobnych ziemian, dla których otwierała się droga albo kariery naukowej, jeśli byli obdarzeni talentem, albo kariery urzędniczej we wciąż rozrastającej się biurokracji.

Chłędowskiemu talentu i pracowitości czy ambicji nie zbywało. Początkowo odebrał podstawowe wykształcenie domowe, potem kolejne klasy gimnazjalne zaliczył w Tarnowie i Nowym Sączu, by ostatecznie zakończyć wykształcenie średnie w wyższych klasach renomowanego krakowskiego Gimnazjum św. Anny, gdzie zdał maturę. Tam też poznał swoich późniejszych kolegów ze świata urzędów, w tym przyszłego premiera K. Badeniego. W 1861 r. rozpoczął studia prawnicze na Uniwersytecie Karola w Pradze; w roku akademickim 1863/64 przeniósł się na Uniwersytet Jagielloński, gdzie w 1867 r. uzyskał stopień doktora. Napisał rozprawę habilitacyjną $O$ kredycie rolniczym $i$ jego instytucjach, lecz nie przystąpił do kolokwium habilitacyjnego. Lata studiów zbliżyły go do wielu później sławnych postaci, jak choćby: Jan Matejko, Karol Frycz, Józef Szujski, Artur Grottger, Cyprian Godebski czy Michał Bałucki. Z tego okresu pochodzi też pasja teatralna, która przyczyniła się do nawiązania znajomości z Heleną Modrzejewską i Antoniną Hoffmanową (wieloletnią towarzyszką życia Stanisława Koźmiana). Chłędowski poznał niemal całą redakcję „Czasu” i „Przeglądu Polskiego”, co miało później duże znaczenie w jego kontaktach towarzyskich i politycznych. Pomoc materialna domu z pewnością mu nie wystarczała, dlatego w trakcie studiów podejmował pracę jako praktykant w kancelariach adwokackich, a potem przyjął posadę koncypienta w Prokuratorii Skarbu, co zresztą było zajęciem dość typowym zarówno dla przyszłych uczonych, jak i biurokratów.

Okres ten jest jednak bardziej interesujący $\mathrm{z}$ racji tego, iż stanowi początek drogi Chłędowskiego jako pisarza. Jego juwenilia w postaci artykułów ukazywały się na łamach lwowskiej „Gazety Narodowej”, krakowskiego „Kraju”, warszawskiego „Słowa”, poza tym był autorem dwóch powieści społecznych Skrupuly i Ella (Kraków 1871-1872) oraz powieści kryminalnej wzorowanej na wziętym pisarzu francuskim Emilu Gaboriau Po nitce do ktębka (Kraków 1872) - dziś o tej części pisarstwa szacownego hofrata mało kto pamięta. Warto jeszcze wspomnieć o tym okresie, ponieważ Chłędowski był wówczas zafascynowany pozytywizmem spod znaku Auguste'a Comte'a, Karola Darwina, Henry'ego T. Buckle'a, Moritza Müllera i innych. Opublikował kilka artykułów głoszących chwałę myślenia i światopoglądu pozytywistycznego, w tym odrzucone przez „Bibliotekę Warszawską" Spekulacje, doświadczenia i dążności realistyczne z powodu rzekomego radykalizmu przekonań autora, które ukazały się we lwowskim „Dzienniku Literackim" pod zmienionym tytułem Realistyczne pojęcia. Czas publikacji (lata 1864-1866) w pełni upoważnia do sądu, iż Chłędowski należał do prekursorów 
pozytywizmu galicyjskiego. Wyraźny ślad tego myślenia i metody odbił się niemal we wszystkich jego późniejszych pracach historycznych. Ważne jest również to, że jego pióro nabrało giętkości i precyzji, co zdecydowało o przyszłej poczytności jego dzieł.

Po pewnych perturbacjach natury personalnej (opisanych w Pamiętniku) Chłędowski zrezygnował z kariery naukowej i wybrał bardziej pewną materialnie posadę praktykanta w Namiestnictwie we Lwowie (1867), przy pełnej aprobacie Gołuchowskiego, który poszukiwał dobrze wykształconych urzędników Polaków w ramach polonizacji niemal całej administracji galicyjskiej. W tym okresie powstały nie tylko wspomniane powieści, lecz także zbiór satyrycznych portretów osobistości galicyjskich pt. Album fotograficzne (wydany pod pseudonimem Kalasanty Kruk, Kraków 1870-1871); rok następny przyniósł pierwsze refleksje z odbytej podróży do Włoch, czyli Szkice z Włoch (Kraków 1873). Co istotne, fascynacja sztuką Italii trwała po kres jego życia. W 1875 r. Chłędowski wstąpił w związek małżeński ze Stefanią Tabęcką, a po jej przedwczesnej śmierci w 1884 r. pozostał już na zawsze stanu wolnego.

Pomijam tu część twórczości tego okresu. Odnotuję tylko jeszcze Królowa Bonę. Obraz czasu i ludzi (Warszawa 1876), która wprawdzie w świetle późniejszych opracowań historycznych wydaje się dość mierna, ale mieści się w nurcie jego zainteresowań. Kariera urzędnicza natomiast nabrała rozpędu zwłaszcza po 1880 r. Wówczas Florian Ziemiałkowski - jako świeżo „upieczony” baron - objął Ministerstwo dla Galicji po Kazimierzu Grocholskim i wziął pod opiekę Chłędowskiego, który przeniósł się do Wiednia, gdzie praktycznie spędził resztę życia. Po dość jałowej i nieciekawej pracy w Ministerstwie Spraw Wewnętrznych został długoletnim urzędnikiem Ministerstwa dla Galicji, powstałego w 1871 r. Status owego ministerstwa był dość podrzędny, gdyż nie wchodziło ono w skład właściwego gabinetu; ponadto nawet przez jakiś czas unikano używania tej nazwy (by nie drażnić Czechów), a sam minister był pozbawiony teki. Nie zmienia to faktu, że w Galicji cieszył się on admiracją, ponieważ dawało to dostęp do Wiednia i rządu oraz pośrednio do Rady Państwa, a w końcu większość spraw galicyjskich przynajmniej przechodziła przez ręce ministra i jego urzędników. $Z$ tego powodu walka o ów fotel niejednokrotnie była zacięta. Chłędowski był nader sumiennym urzędnikiem, co nie przeszkadzało mu wejść znacznie głębiej nie tylko w układy polityczne, ale też poznać ich kulisy, mechanizmy oraz wzajemne zależności. Życie towarzyskie i obracanie się w sferach wyższej biurokracji wiedeńskiej, bogatego mieszczaństwa i finansjery zaowocowało w Pamiętnikach niezliczonymi opisami skandali oraz tyleż trafnymi, co złośliwymi charakterystykami czołowych postaci świata politycznego i towarzyskiego. Tu Chłędowski potrafił być bezwzględny, a okres 30 lat spoczynku dla Pamiętników był w pełni uzasadniony.

Korzystanie z urlopów i wszelkich możliwości zdobycia wolnego czasu na odbywanie podróży po Europie ograniczały jego skromne zasoby finansowe. 
Sytuacja ta jednak znacznie się poprawiła, gdy w 1887 r. okazało się, iż jego rodzinny majątek Wietrzna znajduje się na terenach roponośnych, a był to rozkwit zagłębia naftowego wokół Jasła i Krosna. Chłędowski nie mógł w pełni wykorzystać tych możliwości, ponieważ nie było go stać na założenie własnego przedsiębiorstwa, lecz nawet czynsz za eksploatację terenu przyniósł jemu i jego rodzinie znaczną poprawę. Krótko mówiąc, dzięki temu wydarzeniu narodziła się twórczość z zakresu historii kultury i sztuki. Tym bardziej, że towarzyszyły mu w tym okresie kolejne awanse urzędnicze, w tym na radcę dworu, a otrzymanie tytułu szambelana (1885) otworzyło mu drogę do bywania w Hofburgu i utrzymywania osobistego kontaktu z monarchą, a przy okazji przysporzyło materiału do kolekcjonowania kolejnych anegdot i plotek. Wspomnieć należy również jego dwie podróże do Anglii, czego owocem stała się publikacja, zwiastująca w moim przekonaniu styl dalszych dzieł, zatytułowana Dwie wizyty w Anglii (Lwów 1887), w której umiejętnie połączył pasje „turysty” z obserwacjami stylu życia Anglików różnych stanów i jednocześnie poznanie najważniejszych kolekcji sztuki, ze zbiorami prywatnymi włącznie.

Nie rozwodząc się zbyt długo nad karierą urzędniczo-dworską Chłędowskiego, należy dotrzeć do października 1899 r., kiedy został poinformowany w związku z upadkiem gabinetu Franza Antona Thuna, że jest jako wiceminister dla Galicji brany pod uwagę jako kandydat na ministra. Po skądinąd zabawnych układach $\mathrm{z}$ dotychczasowym ministrem A. Jędrzejewiczem w dniu 3 października z całym ceremoniałem został przed obliczem Franciszka Józefa II zaprzysiężony jako minister wraz z premierem Manfredem von Clarym-Aldringenem i jego gabinetem. Tu trzeba wspomnieć, że zazwyczaj chłodny autor Pamiętnika ulegał emocjom i wzruszeniu. I tak niegdyś koncypient w Prokuratorii Skarbu został siódmym w kolejności ministrem dla Galicji. Była to kariera wręcz zawrotna dla ubogiego szlachcica o miernych perspektywach nawet urzędniczych; tak naprawdę zawdzięczał ją w głównej mierze sobie i umiejętnościom zdobywania poparcia innych, wyżej postawionych. U wielu Polaków, jak relacjonuje sam Chłędowski, wywołało to mieszane uczucia zazdrości, podziwu i „nagłych przyjaźni”.

Kariera ministerialna nie trwała zresztą długo, ponieważ objęła raptem tylko dwa typowo urzędnicze gabinety: wspomnianego von Clary'ego-Aldringena i Heinricha Witteka. Dało to jednak asumpt do pogłębienia wiedzy Chłędowskiego o funkcjonowaniu monarchii na wysokim szczeblu biurokratyczno-administracyjnym tudzież stanowiło źródło dla nieocenionych (choć często złośliwych) charakterystyk ministrów i posłów, zwłaszcza z Koła Polskiego. Tu wyróżnia się nader ciepły jego stosunek do Ignacego Daszyńskiego i podziw dla jego wystąpień parlamentarnych. Bliższe stało się mu także życie dworu i najbliższego otoczenia monarchy, brał bowiem udział w uroczystościach i spotkaniach częściowo oficjalnych, a częściowo prywatnych, które np. dla Mariana Rosco-Bogdanowicza (innego pamiętnikarza tej epoki) były jedną racją żywota i egzystencji 
u dworu i który jako szambelan zasłynął ponoć z niezwykłych uzdolnień tanecznych torujących mu drogę do sfer arystokratycznych, choć z drugiej strony jako pamiętnikarz dostarczył też wielu interesujących informacji i rzecz jasna plotek. Podobnie wypada to porównanie ze wspomnieniami Floriana Ziemiałkowskiego, Leona Bilińskiego, Michała Bobrzyńskiego czy Ignacego Daszyńskiego - w sumie dość bezbarwnych, biorąc pod uwagę rangę polityczną, autorów.

W styczniu 1900 r., wraz z kolejną zmianą rządu, Chłędowski zakończył karierę ministra, rok wcześniej został uhonorowany komandorią Orderu Franciszka Józefa. Po przejściu na emeryturę został zaś zaszczycony przez monarchę godnością Rzeczywistego Tajnego Radcy Dworu wraz z przysługującym mu tytułem „Ekscelencji”, co w Galicji miało niebagatelne znaczenie. Chłędowski zresztą nieco bolał nad koniecznością poniesionego ekspensu na uszycie tzw. małego munduru za niebagatelną kwotę 400 guldenów (,wielki mundur" kosztował 800), by zgodnie z tradycją i protokołem złożyć osobiste podziękowanie na ręce Franciszka Józefa. Z ministerstwa odszedł, jak wspomina Biliński, „z jasnym i pogodnym obliczem", bo tak naprawdę wtedy rozpoczął swoje drugie życie, w pełni zgodne z jego zainteresowaniami i pasjami.

$* * *$

To drugie życie oczywiście nie narodziło się z dnia na dzień. Chłędowski już wcześniej na miarę swych możliwości finansowych odwiedził większość krajów Europy Zachodniej, poznał ich zabytki i zwiedził galerie sztuki, zawierając przy tym wiele znajomości, które później ułatwiały mu dalsze podróże. Ponadto, jeszcze pracując $\mathrm{w}$ namiestnictwie, a potem w ministerstwie, oddawał się lekturze źródeł i dzieł naukowych, które przyniosły konkretny plon w zakresie wiedzy historycznej i studiów nad sztuką. Dzięki temu jego największe monografie zostały opatrzone dość imponującą bibliografią - mimo że nie podzielono jej tradycyjnie na źródła i opracowania, to i tak budzi ogromny podziw. Do tego należy dodać znajomość języków obcych (z niemieckim i włoskim na czele), która znakomicie ułatwiła mu dotarcie do na owe czasy najnowszych prac naukowych. Trzeba przyznać, że jak na biurokratę biorącego jednocześnie czynny udział w życiu towarzyskim był to niemały i zarazem nietypowy dla wiedeńsko-galicyjskiego światka politycznego zakres zainteresowań.

Rodzi się naturalne pytanie o znaczenie twórczości Chłędowskiego wczoraj i dziś. Najczęściej w jego biogramach powtarzają się słowa: ,amator”, „samouk” lub ,popularyzator”. Mają one wydźwięk w pewnym stopniu umniejszający znaczenie jego dorobku. Jest oczywistością, że Chłędowski nie był zawodowym historykiem sztuki i wybitnym uczonym-kolekcjonerem, jak np. Karol Lanckoroński; nie rozwinął też kariery politycznej, naukowej i uniwersyteckiej w dziedzinie prawa, jak Leon Piniński. Był jednak bez wątpienia popularyzatorem tego, 
co dziś można określić jako szeroko rozumiane kulturoznawstwo. Nie starał się o wypracowanie tzw. warsztatu historyka, a tym bardziej nie dbał o cały aparat przypisów i odsyłaczy do źródeł czy opracowań, z których korzystał; nie starał się również o zbudowanie jakiejś syntezy w ramach epok historycznych, którymi się zajmował, a mimo to pozostawił trwały ślad w polskiej i europejskiej kulturze.

Powyższe stwierdzenie, zwłaszcza odnośnie do przeszłości, ma głębokie uzasadnienie w samym fakcie wydań i tłumaczeń najważniejszych dzieł Chłędowskiego. Warto je w tym miejscu przytoczyć: Siena - trzy wydania polskie (1904, 1923, 1969), Berlin (1903, 1913, 1918, 1923), Amsterdam (1931), Sztokholm (1920); Dwór w Ferrarze - cztery wydania polskie (1907, 1909, 1930, 1958), Berlin (1910, 1913), Monachium (1919, 1921, 1934), Amsterdam (1934), Sztokholm (1918); Rzym. Ludzie Odrodzenia - sześć wydań polskich (1909, 1911, 1921, 1933, 1957, 1996), Monachium (1919, 1921, 1922, 1934), Sztokholm (1916, 1920); Rzym. Ludzie Baroku - trzy wydania polskie (1912, 1931, 1957), Monachium (1912, 1914, 1919, 1934), Sztokholm (1916, 1920); Rokoko we Włoszech - trzy wydania polskie $(1912,1931,1957)$, Monachium $(1912,1914,1919,1934)$, Sztokholm (1917, 1922); Historie neapolitańskie. Wiek XIV-XVIII - trzy wydania polskie (1918, 1935, 1959), Berlin (1918, 1920), Sztokholm (1919); Ostatni Walezjusze. Czasy Odrodzenia we Francji - dwa wydania polskie (1921, 1958), Monachium (1922, 1934), Sztokholm (1923). Sądzę, że i dziś niejeden zawodowy pracownik nauki w dziedzinie humanistyki mógłby pozazdrościć Chłędowskiemu liczby wydań polskich i zagranicznych, a przecież bez popularności wśród czytelników, przekładającej się na interesy wydawców, jego prace nie doczekałyby się takiego sukcesu. Inna sprawa, że były to inne czasy, inne książki i inni czytelnicy.

Zbyt śmiałą supozycją byłoby stwierdzenie, iż Chłędowski wypracował czy zdobył pewną metodologię w owych kilkusetstronicowych dziełach. Jeśli pokusić się tu o jakąś refleksję własną, to można ją sprowadzić do stwierdzenia, że spójna jest w nich jedynie metoda prezentacji, którą odnosił czy to do miasta (Rzym, Siena, Ferrara, Neapol), czy do ludzi i ich otoczenia (dwór Walezjuszy i jego obyczaje). Nie był autorem zbyt dokładnym i pedantycznym, co wynikało chyba z pewnego pośpiechu w pisaniu. Czasem, gdy pisze o Lorenzo Medici, nie wiadomo z powodu powtarzania imienia, czy chodzi o il Magnifico, czy o któregoś z jego następców lub krewnych; sytuacja powtarza się, gdy pisze raz o Giovanninim (zdrobnienie), a w kolejnym szkicu o Giovannim, podczas gdy chodzi o tę samą postać. Nie wspominam tu (z racji struktury jego książek) szerzej o wybieganiu i cofaniu się w czasie, które powoduje pewien chaos w odniesieniu do dat i wydarzeń oraz całości chronologii. Jakiś porządek wprowadził sam Chłędowski w dwóch poniekąd koronnych dziełach poświęconych Rzymowi - w jednej kolumnie zamieścił skróconą tablicę synchronistyczną ułożoną według pontyfikatów papieży renesansowych i barokowych, a w drugiej uwzględnił najważniejsze wydarzenia europejskie (w tym polskie), oczywiście wedle własnego uznania. 
Nieuniknione są także powtórzenia, raz zamierzone w zależności od okoliczności historycznych (pontyfikaty Aleksandra VI, Urbana VIII lub Innocentego X), a innym razem wymuszone przez równoległość życia niektórych bohaterów. Rzecz jasna dzisiejszy historyk czy historyk sztuki, architektury lub literatury natychmiast zrewidowałby sądy i oceny Chłędowskiego, kwestionując jego podziały czasowe na renesans, barok czy rokoko, jako że wiele postaci stoi na granicy epok i stylów, w czym nie zgadzają się ze sobą oni sami lub entuzjaści danego okresu historycznego. Te wszystkie zastrzeżenia przyjmijmy jednak z „dobrodziejstwem inwentarza", ponieważ zasługi hofrata Chłędowskiego na polu popularyzacji historii i kultury wydają się niepodważalne - przynajmniej wtedy, gdy ukazywały się kolejne nakłady jego prac.

Wspomniałem wyżej o braku metodologii w znaczeniu profesjonalnym i o zastąpieniu jej przez sposób prezentacji historii. Otóż metoda, jaką przyjął autor, nie jest w historiografii nowością, lecz jest coraz rzadziej stosowana. Chłędowski przedstawił obraz czasu i miejsca poprzez pryzmat poszczególnych wybranych przezeń bohaterów, przeważnie otoczonych przez cały rój postaci innych (czasem nie mniej sławnych) oraz wydarzeń towarzyszących ich życiu. Stąd np. pojawiają się znaczący w historii ludzie, jak Cesare Borgia, którego życiorys urywa się niespodziewanie, jest on bowiem pobocznym bohaterem w stosunku do biografii Katarzyny Sforzy.

W tej metodzie przedstawiania epoki poprzez ludzi interesujące są dwa momenty. Pierwszy może na swój sposób zadziwiać, biorąc pod uwagę skalę zainteresowań autora sztuką w jej każdym wymiarze, co można dostrzec w końcowej części Pamiętników, gdzie jawi się wręcz jako konsument wszystkich jej rodzajów (z malarstwem i rzeźbą na czele), ze sztuką dekoracyjną włącznie (np. zachwyty nad biżuterią René Lalique'a, szkłami Émile'a Gallègo czy wzornictwem porcelany duńskiej). Należy podkreślić, że w jego głównych dziełach sztuka pojawia się jako wtórne odbicie postaci lub miejsca (doskonale zna portrety bohaterów i galerie, w których się one znajdują), lecz stanowi to margines czasem szerszy, a czasem wręcz zanikający. Dygresją na pewno będzie, jak można patrzeć na to samo miejsce - w tym wypadku na Sienę - niegdyś i z bliskiej nam współczesności, jeśli odwołać się do Zbigniewa Herberta i jego Barbarzyńcy w ogrodzie. W tym krótkim eseju poświęconym miastu poeta skupił się niemal wyłącznie na krajobrazie i dziełach sztuki, ale przy tym przelotnie odniósł się także do dzieła Chłędowskiego. Tu trzeba dodatkowo zaznaczyć, że Siena, gdy idzie o konstrukcję i treść, znacznie odbiega od pozostałych dzieł i jest rzeczywiście pewną monografią miasta. Wracając do głównego wątku, jeśli centralną postacią staje się np. Giovanni L. Bernini czy dziś nieco zapomniani Rosalba Carriera lub Antonio Canova, wtedy na jaw wychodzi cała eksperiencja i wręcz smakoszostwo Chłędowskiego w dziedzinie malarstwa, rzeźby i architektury. Zresztą, jeśli spojrzeć na jego dzieła z punktu widzenia chronologii, można dostrzec, iż z biegiem lat ten 
margines stawał się coraz szerszy, by np. w Rokoko we Włoszech oraz Historiach neapolitańskich stać się głównym nurtem, wzbogaconym o rozważania nad literaturą i dramatem (vide Pietro Aretino, Torquato Tasso czy Carlo Goldoni), które zawsze stanowiły dlań ważny punkt odniesienia.

Drugim znamiennym momentem był sam wybór postaci, które stanowiły oś konstrukcyjną dla przeróżnych dygresji historycznych, często zabarwionych anegdotą czy wręcz plotką. Był to wybór całkowicie dowolny, subiektywny i w zasadzie niczym nieskrępowany. Wcale nie chodziło tu autorowi o postaci zajmujące pozycje pierwszoplanowe w historii. Wystarczy, że czasem przebywały one w orbicie czasów i miejsc, o których pisał. Czasem decydowała też jego fascynacja daną osobą lub uczucie sympatii bądź antypatii. Oczywiście w tak krótkim szkicu nie sposób pomieścić należytej egzemplifikacji, toteż ograniczę się jedynie do wyrywkowych przykładów.

Jednym z nich jest wspomniany Aretino, uchodzący dość powszechnie za postać z głębokiego cienia, uznawany za czołowego paszkwilanta, pornografa i szantażystę swojej epoki. Chłędowski nie negował jego postawy i roli. Uważał, że na ten mało chlubny piedestał wyniósł go niepospolity talent, dzięki któremu najpotężniejsi i najsławniejsi ludzie ówczesnego świata płacili mu, aby pohamował swe pióro. Jednocześnie dostrzega w nim jednego z prekursorów współczesnego mu dziennikarstwa (my moglibyśmy jeszcze dodać - dziennikarstwa tabloidowego czy wręcz hejtu internetowego). Pokazuje też jego bardziej „ludzką” twarz człowieka hojnego i lojalnego wobec rodziny, przyjaciół, a nawet nieznajomych. Być może były to zabiegi daremne, bo raz utrwalona legenda czy mit nie ulegają zniknięciu czy osłabieniu, lecz niewątpliwie Chłędowski w jakiejś mierze ten obraz uzupełnił. Czasem poświęcał portret również tym, którzy znaczną część życia spędzili poza rodzinnymi stronami, lecz jego zdaniem byli odbiciem epoki, w jakiej żyli, a poza tym byli na owe czasy „,celebrytami”, jak Giovanni Casanova; dla innych przeznaczał kilka stron, np. hrabiemu Cagliostro (recte Józef Balsamo), a właściwie jego ostatnim latom życia i śmierci w twierdzy San Leo, notabene zburzonej potem przez legion Dąbrowskiego. Co więcej, ludzie już z innej epoki myślenia znaleźli swoje miejsce u Chłędowskiego, jak chociażby lord Byron z racji swego długiego i twórczego pobytu we Włoszech (1814-1823). Oczywiście nie przytaczam tu jako przykładów głównych postaci renesansu, baroku czy doby rokoka, poczynając od pontyfikatu kolejnych papieży, poprzez sławnych tyranów włoskich polis czy wybitnych wodzów (przeważnie zresztą kondotierów), czy wreszcie pisarzy tej doby, choć np. sylwetka Baltasare'a Castglione jest godna uwagi. Wszyscy oni zasługują na osobny artykuł, ponieważ Chłędowski nie zawsze równomiernie rozkładał blaski i cienie kładzione na swych bohaterów, więc zwykły szkic tu z pewnością nie wystarczy.

Zamiłowanie autora do płci pięknej, czego nie ukrywa w Pamiętnikach, zawiodło go w stronę zwrócenia szczególnej uwagi na rolę kobiet w czasach, które 
opisuje. Nie bez powodu w omawianych tu dziełach 21 rozdziałów traktuje o bohaterkach, a tylko dwa - o roli kobiet w dziejach Sieny i na dworze Walezjuszy. Nie wspominam tu o wszystkich pozostałych rozdziałach, gdzie miejsce kobiet bynajmniej nie jest tłem dla głównych bohaterów czy wydarzeń, albowiem jest ich legion. Fascynacje ich charakterami, wpływem na bieg wydarzeń, zamiłowaniami czy profesją są całkowicie różne. Czasem był to wyimek z ich życiorysów (jak pobyt królowej Krystyny w Rzymie, gdzie zmarła), czasem zaś opisywał wpływ, jaki wywierały na życie polityczne i towarzyskie, pochodząc z nieco innego kręgu kulturowego (jak w przypadku sióstr de la Trèmouille). Niewątpliwie Chłędowskiego fascynowały kobiety o wyraźnych cechach charakteru lub zdolnościach artystycznych. Galeria tych postaci jest nader barwna: od królowych po zawodowe kurtyzany; od wojowniczek po artystki malarki; od Katarzyny Medycejskiej (promotorki Nocy św. Bartłomieja) po łagodną, dowcipną i intelektualnie rozwiniętą kurtyzanę Tulię d'Aragona; od prawdziwej „wilczycy” Katarzyny Sforzy, godnej przeciwniczki Cesara Borgii i matki słynnego dowódcy Giovanniego Medici zwanego del Bande Nere (spod Czarnych Choragwi), po słynną w całej Europie ze swych portretów elit panujących politycznie i finansowo miniaturzystkę i intelektualistkę Rosalbę Carrierę. Znów pojawia się tu dylemat, czy wspominać o tak wybitnych indywidualnościach, jak Vittoria Colonna, czy tak pięknych, jak Joanna d'Aragona lub Giulia Gonzaga. Chłędowski lubił czasem przesadzać w swoich sympatiach i opisach lub rewidować narosłe w literaturze legendy, by przytoczyć cause cèlèbre rodziny Cenci, gdzie słynną Beatrice określił mianem „zwykłej zbrodniarki”, a jej śmierć - mianem „tytułu procesu kryminalnego”.

Autor nie unikał wątków polskich, o ile miał po temu okazję. Odwołam się tu wyrywkowo tylko do kilku przykładów. Chłędowski np. wyraził wręcz zdumienie, iż Jan Długosz w czasie jubileuszu w 1450 r., przebywając przez 17 dni w Rzymie, zupełnie nie napomknął o wrażeniach, jakie powinno było na nim zrobić „Wieczne Miasto”, oraz nie dostrzegł ani zabytków starożytnych, ani tych pochodzących z czasów późniejszych, mimo że istniały już wówczas swoiste przewodniki zwane Mirabiliami. Osobiście mnie to nie dziwi, bo większość pielgrzymów (w szczególności duchownych) zajęta była zapewne uroczystościami kościelnymi, a nie zwiedzaniem miasta. Zgoła innym wątkiem jest sprawa Filipa Buonacorrsiego, który wplątał się w spisek zawiązany przez niezbyt zrównoważonego Pomponiusza Laetusa. Otóż, wstępując do jego akademii gromadzącej zapalonych „humanistów” oddanych idei wskrzeszenia tradycji dawnego Rzymu, postawił sobie za cel obalenie papieża Pawła II. Buonacorrsi przybrał sobie nazwisko akademickie Kallimach i stał się następnie niemal formalnym przywódcą spisku. Jak wspomina Chłędowski, sam spisek został ujawniony przez gadulstwo jego uczestników i spowodował ucieczkę głównych spiskowców, a Kallimach po dość okrężnej drodze przez Konstantynopol - odnalazł się w Polsce pod opieką biskupa Grzegorza z Sanoka, by potem zostać nauczycielem synów króla Kazi- 
mierza Jagiellończyka. Dalsze jego losy, podobnie jak jego dzieła wraz z przypisywanymi mu kontrowersyjnymi Radami, są doskonale znane w polskiej literaturze przedmiotu, a w kościele oo. Dominikanów w Krakowie można oglądać jego grób z płytą wykonaną przez Wita Stwosza przedstawiającą dobrze znany w renesansie temat „Uczony w pracowni”. Trzecim polskim epizodem może być np. poselstwo Jerzego Ossolińskiego do papieża Urbana VIII, też dobrze znane z literatury historycznej w zakresie jego celów i wątpliwych efektów dyplomatycznych, co nie przeszkodziło Chłędowskiemu w opisaniu całego orszaku oraz pompy towarzyszącej owemu wydarzeniu wraz z przysłowiowymi dwiema złotymi podkowami „zgubionymi” po drodze. Autor zresztą we wszystkich swoich dziełach śledził liczne ślady polskie we Włoszech, czasem nawet zbyt drobiazgowo i przesadnie. Jest to jednak akcent ważny z powodu tłumaczeń i wydań zagranicznych.

$* * *$

Subiektywne spojrzenie Chłędowskiego na historię i sztukę spotykało się z różnym odbiorem, o czym wspomina w Pamiętniku i korespondencji. Zwłaszcza sfery klerykalne Krakowa i Lwowa nie bez racji wypominały mu wolnomyślność i wysuwanie na plan pierwszy postaci niektórych papieży, o których Kościół wolałby zapomnieć, tudzież wdawanie się w szczegółowe opisy obyczajowości renesansu i baroku. Tymczasem większość ocen prasy, recenzentów i samych czytelników była pełna zachwytu nad erudycją autora i potoczystością jego narracji. Oczywiście było to znakiem czasu i stylu pisania mieszczącego się w pełni w konwencji literackiej fin de siècle'u jako refleksje Europejczyka podróżującego po kulturze europejskiej. Tymczasem gdy dziś czyta się właśnie tę warstwę historyczno-faktograficzną wraz z opisami sposobów sprawowania władzy, jej metod czy mentalności ludzi, którzy stali się bohaterami poszczególnych rozdziałów jego prac, łatwiej nam zrozumieć, że treść zawarta w dziełach Niccolò Machiavellego jest niczym więcej niż budowaniem doktryny opartej na obserwacji rzeczywistości - rzeczywistości „włoskiej polityki”, której piętno sięga dnia dzisiejszego. Kraina wielkich namiętności, wojen, zbrodni, fałszu i kłamstwa wydała jednocześnie wielkie dzieła sztuki i architektury. Był to związek nierozerwalny, tworzący nową epokę oraz nowe horyzonty myślenia i twórczości - epokę, w której samoświadomość „czegoś nowego w dziejach” była dalece rozwinięta, szczególnie wśród elit intelektualnych i artystycznych (np. Matteo Palmieri czy Leon B. Alberti).

Zgodzić się jednak wypada, że z pewnością nie były to ani wówczas, ani dziś rozprawy naukowe, ale - jak wspomniano wcześniej - mieściły się one w ramach szeroko pojętego kulturoznawstwa i w sferze popularyzatorstwa. Czytając prace Chłędowskiego dzisiaj, możemy z owej staroświeckości narracji stworzyć zarzut, lecz gdy się nieco zastanowić, to obrazy renesansu czy baroku nie tracą swoich 
walorów poznawczych i mogą się mierzyć chociażby z szeroko znanymi i wciąż cytowanymi Obrazami Włoch Pawła Muratowa czy z uchodzącymi dziś za klasykę literatury pięknej Kronikami włoskimi Stendhala - nie ma w tym wielkiej przesady, biorąc pod uwagę m.in. zrewidowanie wspomnianej sprawy rodziny Cencich. Dziś w każdym razie czytelnik oswojony z kulturą przemocy (telewizja, internet oraz powieści z gatunku sensacyjnego) nic szokującego w historycznych przykładach nie odnajdzie, zwłaszcza jeśli oglądał kiczowate i niezbyt zgodne z prawdą seriale typu Rodzina Borgiów czy Medyceusze itd. Zakładając rzecz jasna, że taki czytelnik sięgnie do dzieł Chłędowskiego.

Popularność dzieł Chłędowskiego miała swoiste przypływy i odpływy, o czym świadczą przytoczone wcześniej daty kolejnych wydań i tłumaczeń. Pierwszą i najbardziej znaczącą falę popularności można odnotować w latach od ukazywania się pierwszych wydań (tj. na początku XX w.) do wybuchu I wojny światowej. Drugi przypływ popularności nastąpił już po zakończeniu wojny i trwał do początku lat 30. XX w. Trzecie i jak na razie najpełniejsze wydanie jego dzieł miało miejsce w Polsce na przełomie lat 50. i 60. XX w., kiedy z inicjatywy Państwowego Instytutu Wydawniczego w ujednoliconej szacie graficznej ukazały się niemal wszystkie najważniejsze monografie. Obecnie to raczej sam Chłędowski i jego twórczość są przedmiotem badań i dociekań naukowych, chociażby z racji jego życia czy czasu, jaki nas oddziela od autora i jego dzieła. Jego nazwisko pojawia się rzadko zarówno wśród historyków sztuki, jak i kulturoznawców. Częściej odnaleźć go można pośród badaczy epoki monarchii habsburskiej czy dziejów Galicji. Może dlatego warto go nadal przypominać, był bowiem osobowością nietuzinkową i nie do końca mieszczącą się w czasach, w jakich przyszło mu żyć. Gwoli ścisłości biograficznej należy dodać, że Kazimierz Chłędowski zmarł 26 marca 1920 r. w swym wytwornym, wypełnionym antykami mieszkaniu przy Aleegasse $11 \mathrm{w}$ Wiedniu.

\section{BIBLIOGRAFIA}

Barycz H., Wśród gawędziarzy, pamiętnikarzy i uczonych galicyjskich. Studia i sylwety z życia umysłowego Galicji XIX w., t. 1-2, Kraków 1963.

Białostocki J., Refleksje i syntezy ze świata sztuki, Warszawa 1978.

Białostocki J., Symbole i obrazy, t. 1, Warszawa 1982.

Biliński L., Wspomnienia i dokumenty, t. 1-2, Warszawa 1924-1925.

Biogramy uczonych polskich, cz. 1: Nauki społeczne, z. 1: A-J, Wrocław 1983.

Bobrzyński M., Z moich pamiętników, Wrocław-Kraków 1957.

Daszyński I., Pamiętniki, t. 1-2, Kraków 1926.

Jedynak S., Lwowskie początki pozytywizmu polskiego, „Galicja. Studia i Materiały. Czasopismo Instytutu Historii Uniwersytetu Rzeszowskiego" 2016, nr 2, DOI: https://doi.org/10.15584/galisim.2016.2.5. Kazimierz Chłędowski - pisarz i badacz kultury, red. J. Miziołek, J. Maj, Krosno 2007.

Knot A., Przedmowa do drugiego wydania, [w:] K. Chłędowski, Pamiętniki, t. 1, Kraków 1957.

Kowalczuk U., Europejczyk w podróży casus Kazimierza Chłędowskiego, [w:] Europejczyk w podróży 1850-1939, red. E. Ihnatowicz, S. Ciara, Warszawa 2010. 
Kowalczuk U., Rzym w refleksji Kazimierza Chtędowskiego, [w:] Obrazy stolic europejskich w piśmiennictwie polskim, red. A. Tyszka, Łódź 2010.

Kozłowska H., Z problematyki przełomu pozytywistycznego w Galicji, „Kwartalnik Historyczny” 1975, z. 3.

Literatura polska. Przewodnik encyklopedyczny, t. 1: A-M, Warszawa 1984.

Rosco Bogdanowicz M., Wspomnienia, t. 1-2, Kraków 1959.

Stachura-Lupa R., Pisać jak Gaboriau: o „Po nitce do klębka” Kazimierza Chłędowskiego, „Annales Universitatis Paedagogicae Cracoviensis. Studia Historicolitteraria” 2013, nr 13.

Wasylewski S., Chłędowski Kazimierz, [w:] Polski Słownik Biograficzny, t. 3, Kraków 1937.

Wasylewski S., Życie polskie w XIX wieku, Kraków 1962.

Wysocki A., Sprzed pót wieku, Kraków 1974.

Ziemiałkowski F., Pamiętniki, Kraków 1904.

\section{SUMMARY}

The essay presents the life and work of Kazimierz Chłędowski (1843-1920), partly in recognition of his political merit, but first of all to acknowledge his contribution to cultural studies and the popularization of knowledge about the Renaissance and the Baroque. Being a mere clerk and occupying at first the lowest post in the administration of Galicia, the part of the Austro-Hungarian Monarchy, with time Chłędowski raised to the position of the minister for Galicia in the Austrian government. Throughout his career and during the retirement he wrote several powerful monographs devoted to the history and culture of the Renaissance and the Baroque in Italy and France. His works had many re-editions in Poland and their translations won great popularity mainly in Germany and Scandinavia. Today Chłędowski seems to be a rather forgotten figure, hence the idea of writing this essay.

Keywords: Austro-Hungarian Monarchy; Galicia; Renaissance; Baroque; Rococo; Italy; France; Rome; Ferrara; Siena; Naples; Paris

\section{STRESZCZENIE}

W eseju została przedstawiona postać Kazimierza Chłędowskiego (1843-1920) gwoli przypomnienia jego zasług po części politycznych, lecz głównie na polu kulturoznawstwa i popularyzacji wiedzy o renesansie i baroku. Chłędowski jako urzędnik przeszedł drogę od najniższych stanowisk w administracji Austro-Węgier i Galicji jako kraju koronnego, po stanowisko ministra dla Galicji w rządzie austriackim. W trakcie swej pracy, a potem na emeryturze, stworzył kilka potężnych monografii poświęconych dziejom oraz kulturze renesansu i baroku we Włoszech i Francji. Jego prace cieszyły się wielką popularnością na ziemiach polskich oraz miały wiele nakładów i thumaczeń, głównie w Niemczech i Skandynawii. Dziś wydaje się postacią nieco zapomnianą, stąd cel napisania tego eseju.

Słowa kluczowe: monarchia austro-węgierska; Galicja; renesans; barok; rokoko; Włochy; Francja; Rzym; Ferrara; Siena; Neapol; Paryż 